\title{
NEUROCYSTICERCOSIS IN A PRESCHOOL-AGE CHILD
}

\author{
CASE REPORT
}

\begin{abstract}
MARCIO M. VASCONCELOS, MARCIA REGINA S. RAMOS**, PRISCILA JORDAIM SCHWAN ${ }^{* *}$, ROMEU DOMINGUES ${ }^{* * * *}$, KELLY CRISTINA T. DANTAS ALENCAR ${ }^{* * * *}$, GESMAR HADDAD HERDY $Y^{* * * * *}$
\end{abstract}

\begin{abstract}
Neurocysticercosis is a frequent cause of epilepsy and other neurologic abnormalities in all age groups, however by virtue of its prolonged incubation period as well as young children's nutritional habits, it is rarely seen in preschool-age children. The objective of this study is to report the case of a $21 / 2$ year-old child who presented with new-onset seizures. Her diagnostic features, including neuroradiologic findings, are described and compared with the literature. No matter how young he or she may be, every child who presents with newonset seizures or other unexplained neurologic features and whose CT or MRI shows cystic lesions or contrastenhancing rounded lesions should raise a suspicion of neurocysticercosis.
\end{abstract}

KEY WORDS: cysticercosis, CNS, childhood, CT, MRI.

\section{Neurocisticercose em uma criança pré-escolar: relato de caso}

RESUMO - A neurocisticercose é causa freqüente de epilepsia e outras manifestações neurológicas em todas as faixas etárias, mas devido ao seu período de incubação longo e aos hábitos alimentares das crianças pequenas, raramente é vista em pré-escolares. O objetivo deste estudo é descrever o caso de uma criança de 2,5 anos de idade que se apresentou com convulsões de início recente. As manifestações clínicas que levaram ao diagnóstico e os achados neurorradiológicos são descritos e comparados com a literatura. Até mesmo nas menores faixas etárias, toda criança que se apresentar com convulsões ou outras manifestações neurológicas inexplicadas e cuja TC ou RM mostrar lesões císticas ou lesões arredondadas captantes de contraste deve levantar a suspeita de neurocisticercose.

PALAVRAS-CHAVE: cisticercose, SNC, infância, TC, RM.

Neurocysticercosis (NC) is an infestation of the central nervous system (CNS) by Taenia solium larval stage. Its transmission occurs with oral intake of $\mathrm{T}$. solium eggs contained in water and food contaminated with feces from humans who harbor adult T. solium ${ }^{1}$. Once ingested, eggs hatch in the gastrointestinal tract, and their embryos penetrate intestinal mucosa and reach the CNS by means of hematogenous seeding. Autoinfestation is possible as well. Clinical picture is variable, depending on the location, number, size, and age of the cysticerci, but the infestation sometimes is asymptomatic. Although cysts can develop in any human tissue, they have a predilection for the CNS, skeletal muscle, subcutaneous tissue, and the eye ${ }^{2}$. Clinical features due to cyst location in the CNS, such as seizures, signs of increased intracranial pressure, apoplexy, meningitis, and psychiatric disturbances $^{3,4}$, develop more frequently when a cysticercus leaks its toxic content and incites a

Hospital Universitário Antônio Pedro (HUAP) - Universidade Federal Fluminense (UFF) - Niterói RJ, Brazil: *Adjunct Professor of Pediatrics, HUAP-UFF. Ex-Fellow in Child Neurology at Children's Hospital, George Washington University, Washington, DC, USA; **Post-graduate student, Department of Pediatrics, HUAPUFF; ${ }^{* * *}$ Forth-year medical student, HUAP-UFF; ${ }^{* * * *}$ Medical Director and Chief of Neuroradiology, IRM Radiologic Clinic; ${ }^{* * * * *}$ Forth-year medical student, HUAP-UFF; ${ }^{* * * * * *}$ Full Professor of Pediatrics, Department of Pediatrics, Chairwoman, HUAP-UFF. Aceite: 7-junho-2000.

Dr. Marcio M Vasconcelos - Rua das Laranjeiras 391 / 208 - 22240-002 Rio de Janeiro RJ - Brasil. E-mail:mmvascon@centroin.com.br. 
severe local inflammatory reaction. A variety of uncommon neurologic presentations, such as dorsal midbrain syndrome, hemorrhagic stroke, and paraplegia, have also been described ${ }^{5}$. The highest prevalence rates of $\mathrm{NC}$ in Brazil has been reported to vary from 4 to $18 \%$, in association with hyperendemic areas of $T$. solium infestation ${ }^{6}$. However, based upon large series of cases and using various diagnostic methods, several Brazilian authors ${ }^{7-9}$ have reported a NC prevalence rate of 1$1.5 \%$. It is estimated that there are 50 million carriers of $\mathrm{T}$. solium cysticerci worldwide ${ }^{10}$. Cases are rarely seen in infants and preschool-age children ${ }^{11}$. The objective of this study is to report the case of a $2 \frac{1}{2}$ year-old child, focusing on its diagnostic and neuroradiologic findings.

\section{CASE}

A previously healthy, 2 1/2 year-old girl from a rural area, Miracema, Rio de Janeiro, presented with fever, vomiting, neck rigidity, headache, and seizures lasting approximately two hours. Cerebrospinal fluid (CSF) analysis showed 32 cells ( $80 \%$ polymorphonuclear leukocytes), a protein level of $118 \mathrm{mg} / \mathrm{dL}$, and a glucose level of $70 \mathrm{mg} / \mathrm{dL}$. Although her CSF Gram stain and bacterial cultures were negative, she was presumptively diagnosed with bacterial meningitis and treated accordingly with antibiotics and anticonvulsants. Soon after hospital discharge, she had recurring vomiting, headache, and right motor partial seizures. She was referred to a tertiary center, where initially her seizures did not respond to treatment with phenytoin and diazepam. A head computerized axial tomography (CT), with and without contrast (Fig 1), revealed three round, ring-enhancing lesions distributed in the brain cortex and subcortical cerebral white matter. A diagnosis of NC was suspected and then demonstrated through the following serologic tests: serum complement fixation titer 1:32, and serum immunofluorescence titer 1:160; in CSF, enzyme-linked immunosorbent assay (ELISA) was positive, while complement fixation test was negative. Specific therapy consisted of albendazole, $15 \mathrm{mg} / \mathrm{kg} /$ day orally (PO) for eight days, and intravenous (IV) dexamethasone for the first three days. Anticonvulsant therapy included IV phenytoin, followed by PO carbamazepine. There was a progressive improvement in seizures, with definitive remission after four weeks. Brain magnetic resonance imaging (MRI) (Fig 2, 3A) obtained on day 4 of admission revealed two additional cysts that were not detected at head CT and marked perilesional edema. Two and a half months later, brain MRI was repeated (Fig 3B), showing virtual disappearance of pericystic edema and faint ring-enhancement of a cyst capsule. The patient has remained seizure-free on oral carbamazepine for two years.

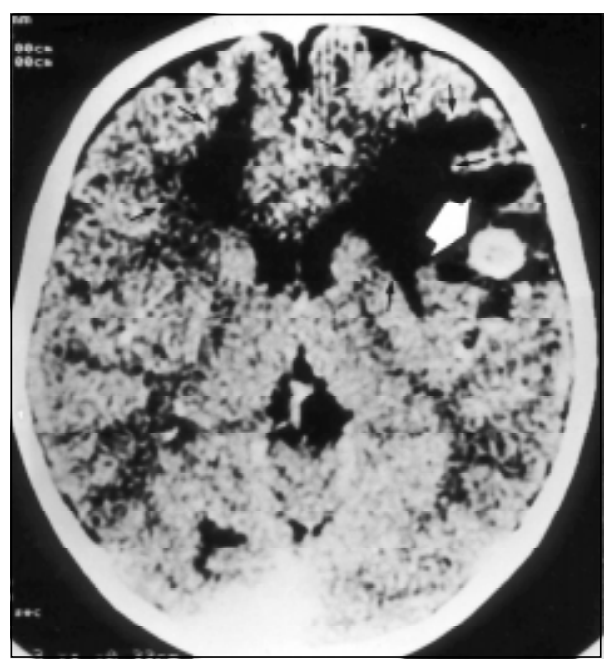

Fig 1. Axial head CT at the basal ganglia level on day one of admission shows a hyperdense rounded lesion (large white arrow), with its center being somewhat less dense, in left frontal subcortical area, and severe bifrontal white matter swelling (small black arrows).

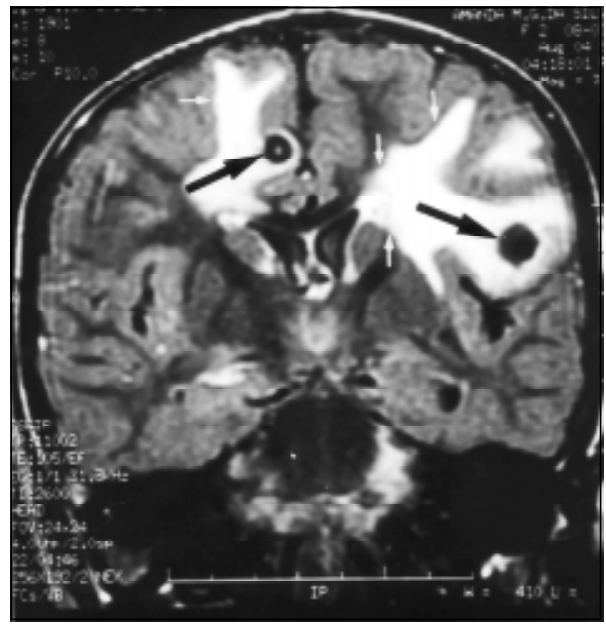

Fig 2. Coronal T1-weighted $(T R=11002 \mathrm{~ms}, T E=$ $105 \mathrm{~ms}$ ) MRI with fat suppression and fluid attenuated inversion recovery (FSEIR) obtained on admission day 4. Two hypointense rounded lesions (large black arrows) are shown associated with marked surrounding vasogenic edema (small white arrows). 


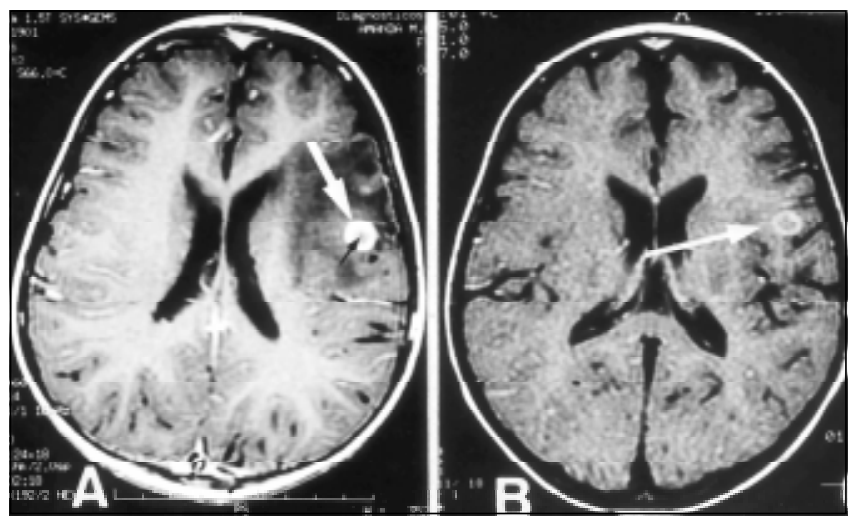

Fig 3. A, Axial T1-weighted $(T R=466 \mathrm{~ms}, T E=14 \mathrm{~ms})$ MRI after gadolinium administration. There is a markedly ring-enhancing cyst (large white arrow). $B$, Axial T1-weighted $(T R=450 \mathrm{~ms}, T E=23 \mathrm{~ms})$ MRI after gadolinium administration obtained $21 / 2$ months later shows virtually no edema and subtle ring-enhancement of the cyst shown in Fig. 3A (white arrow).

\section{DISCUSSION}

Neurocysticercosis has been considered to be rare among young children due to its long incubation period (average, 7 years $)^{11}$. Other likely reasons for this low incidence would be young children's nutritional habits and their unusual exposure to T. solium eggs outdoors. Geme et al. ${ }^{12}$ reported that children younger than 5 years of age represented only 2-3\% of all cases in large literature series. Among 800 cases diagnosed through antibody detection in the CSF, Spina-França et al. ${ }^{7}$ found that $3.75 \%$ were five years old or younger. NC has been described in children as young as 7 months of age ${ }^{3}$. When it does occur, children younger than 3 years of age tend to develop multiple cysts ("miliary cysticercosis"), the pathophysiology of which may be related to an immature immune system $^{13}$. On the other hand, when one considers all age groups, $70 \%$ of patients with epilepsy secondary to NC present with a solitary Cysticercus granuloma in the $\mathrm{CNS}^{2}$.

Serologic tests are the test of choice to confirm a suspected diagnosis of NC, however their sensitivity is fairly poor and is inversely correlated with the number of lesions that are present in a given patient ${ }^{12}$. The most effective serologic test is the enzyme-linked immunotransfer blot (EITB), and it is reportedly more sensitive in serum than in $\mathrm{CSF}^{12}$. A stool examination for ova and parasites should be performed in both the patient and his family members. Recently, use of the technique of polymerase chain reaction has been described for the establishment of a diagnosis of NC in a patient with atypical presentation ${ }^{14}$.

Neuroimaging studies ${ }^{15-17}$ constitute a rather effective tool in patients suspected to have NC. Byrd et al. ${ }^{15}$ described the head CT findings in 30 adults and 15 children (age range, 6-17 years) with $\mathrm{NC}$, who were classified in four groups according to cyst location: parenchymatous (11 children), ventricular-cisternal ( 1 child), ependymal-meningeal ( 1 child), and mixed ( 2 children). Children more commonly showed cystic (ring-enhancing) lesions or diffuse contrast-enhancing lesions, while the most common CT appearance in adults was one of calcified lesions. When a lesion was solitary, CT without contrast was either normal or detected a small area of hypodensity due to edema, however contrast administration identified a round or oval lesion. This findings suggest that, for a given patient with new onset seizures, a head CT without contrast administration - the most frequently used neuroimaging study in that setting - does not provide sufficient information to rule out a structural lesion.

Dumas et al. ${ }^{16}$ reported on the radiological progression of $15 \mathrm{NC}$ lesions that were followed with serial MRI studies, and were able to define five stages of neuroradiologic evolution, according 
to cysticercus content signal-intensity compared with CSF, presence and degree of surrounding edema, and contrast enhancement. Lesions in stage 1 resolved without progression to subsequent stages in response to specific treatment, while stage 4 lesions involuted even without treatment. Specific treatment seemed to hasten evolution of lesions in stages 2 and 3. Although this study followed a small series of five patients, this is an evidence in favor of treatment for patients with early lesions. Additional research is necessary to clarify the role of neuroimaging studies in the decision regarding which patients would benefit from specific therapy.

Specific treatment may be instituted with either praziquantel or albendazole. The authors favored the last choice as it requires a shorter course. Combination of dexamethasone with the anticysticercus drug may be appropriate for the first three days of therapy ${ }^{12}$, in order to reduce an inflammatory reaction triggered by cysticercus breakdown in CNS.

In the present case, brain MRI detected five cystic lesions in stage 3 and was superior to CT, which had found only three such lesions. The two cysts that were missed by CT were very close to the cranial vault. Accordingly, both CT and MRI provide useful evidence for diagnosis, although the latter is more sensitive, as it is best suited to detect incipient lesions ${ }^{12}$ or the ones that are too close to bone structures. Head CT continues to be superior for detection of calcified lesions ${ }^{17}$, however this finding alone may be misleading, as one should be cautious before assigning new-onset neurologic manifestations to calcified NC lesions ${ }^{18}$.

In conclusion, in endemic areas such as many regions in Brazil, every child who presents with seizures or otherwise unexplained neurologic features and whose CT or MRI shows cystic lesions or contrast-enhancing rounded lesions should raise a suspicion of $\mathrm{NC}$, no matter how young he or she may be.

\section{REFERENCES}

1. Souza AQ, Sa HLC, Queiroz TRBS, Horta QWG, Pearson RD. Neurocysticercosis in Ceará state, Northeastern Brazil: a review of 119 cases. Am J Trop Med Hyg 1998;58:759-762.

2. Carpio A, Escobar A, Hauser WA. Cysticercosis and epilepsy: a critical review. Epilepsia 1998;39:1025-1040.

3. Takayanagui OM, Jardim E. Aspectos clínicos da neurocisticercose: análise de 500 casos. Arq Neuropsiquiatr 1983;41:50-63.

4. Lefèvre AB, Diament AJ, Valente MI. Distúrbios psíquicos na neurocisticercose em crianças. Arq Neuropsiquiatr 1969;27:103-108.

5. Sawhney IMS, Singh G, Lekhra OP, Mathuriya SN, Parihar PS, Prabhakar S. Uncommon presentations of neurocysticercosis. J Neurol Sci 1998;154:94-100.

6. Singh G. Neurocysticercosis in South-Central America and the Indian Subcontinent: a comparative evaluation. Arq Neuropsiquiatr 1997;55:349-356.

7. Spina-França A, Livramento JA, Machado LR. Cysticercosis of the central nervous system and cerebrospinal fluid: immunodiagnosis of 1573 patients in 63 years (1929-1992). Arq Neuropsiquiatr 1993;51:16-20.

8. Gonçalves-Coêlho TD, Coêlho MDG. Neurocysticercosis in Paraiba, Northeast Brazil: an endemic area? Arq Neuropsiquiatr 1996;54:565-570.

9. Chimelli L, Lovalho AF, Takayanagui OM. Neurocisticercose: contribuição da necrópsia na consolidação da notificação compulsória em Ribeirão Preto-SP. Arq Neuropsiquiatr 1998;56:577-584.

10. Centers for Disease Control. Update: International task force for disease eradication. MMWR Morb Mortal Wkly Rep 1992;41:197-198.

11. Stamos JK, Rowley AH, Hahn YS, Chadwick EG, Schantz PM, Wilson M. Neurocysticercosis: report of unusual pediatric cases. Pediatrics 1996;98:974-977.

12. Geme JWS III, Maldonado YA, Enzmann D, Hotez PJ, Overturf GD, Schantz PM. Consensus: diagnosis and management of neurocysticercosis in children. Pediatr Infect Dis J 1993;12:455-461.

13. Ostrosky-Zeichner L, Estañol B. Immunopathogenesis of neurocysticercosis: is damage mediated by the host immune response? Int J Parasitol 1999;29:649-650.

14. Meri T, Jokiranta TS, Granat S, Collander F, Valtonen M, Meri S. Diagnosis of atypical neurocisticercosis by polymerasse chain reaction analysis: case report. CID 1999;28:1331-1332.

15. Byrd SE, Locke GE, Biggers S, Percy AK. The computed tomographic appearance of cerebral cysticercosis in adults and children. Radiology 1982;144:819-823.

16. Dumas JL, Visy JM, Belin C, Gaston A, Goldlust D, Dumas M. Parenchymal neurocysticercosis: follow-up and staging by MRI. Neuroradiology 1997;39:12-18.

17. Noujaim SE, Rossi MD, Rao SK, et al.. CT and MR Imaging of Neurocysticercosis. Am J Neuroradiol 1999;173:1485-1490.

18. Narata AP, Arruda WO, Uemura E, et al. Neurocisticercose: diagnóstico tomográfico em pacientes neurológicos. Arq Neuropsiquiatr 1998;56:245-249. 